\title{
Agglomeration of Firms into Technological Districts: the Case of 22@ Project in Barcelona
}

\author{
Òscar Mascarilla Miró ${ }^{1}$ \\ Senior Lecturer in Economics \\ Department of Economic Theory \& CAEPS \\ University of Barcelona \\ Diagonal 690 - 08034 Barcelona \\ omascarilla@ub.edu
}

\begin{abstract}
This paper presents a theoretical analysis of the complex process of agglomeration of firms into technological districts when cities are also competing for them. Positive spillovers tend to make firms locate in the same area, while congestion effects limit this process. Thus, for any given city there exists an optimal number of firms. If there are fewer firms, face competition under increasing returns to scale, with path dependence effects. Hence, if firms are relatively scarce, not all cities will be occupied by firms at the optimal level. The problem of a firm is to choose an optimal city, expecting rational behaviour from other firms. A factor such as office rent
\end{abstract}

${ }^{1}$ The author acknowledges the support of the Generalitat de Catalunya for the research project 2005-SGR-460 and of the Ministry of Science and Technology for the project CYCIT SEJ2005-03196/ECON. 
depends on city size, while wage costs and spillover effects also depend on the number of firms there. Technological firms choose to agglomerate in those cities where their profits will be maximized after optimal entry. Under certain conditions there exists an equilibrium allocation, where all firms are located in the cities with the best parameters. Since cities are different, their attractiveness also differs. This paper also presents an empirical analysis of the advantages and disadvantages of the emerging technological district 22@ in Barcelona. At present, Barcelona needs state intervention to create a critical mass of technological firms in this area. On the empirical side, we analyse the potential effect of investment in infrastructure in Barcelona in order to improve its attractiveness. In particular, we are interested in the factors that may be responsible for the growing density of technological firms located in 22@ district.

Keywords: Location of technological firms, External economies, Hierarchy of cities.

JEL Classification: L6, R3, R12.

\section{INTRODUCTION}

This article combines theoretical and empirical approaches. In the first part, the theoretical section, we study the process of concentration of firms and the factors that may be responsible for the growing density of technological firms in a particular technological district. In the second part, the empirical section, we discuss the future of technological district 22@ in Barcelona.

In reality, we have different types of firms (local, national and international) and there is heterogeneity across the cities (not only size, but other factors matter as well). We try to identify what factors, other than size, may give an advantage to a city, and then apply this approach to the case of the city of Barcelona and its technological district 22@.

\subsection{Practical importance}

At the present time, the area of Barcelona presents opportunities for rapid technological development. The development of the city is a very complex process, because in the age of globalization the competition between world cities for attracting multinational firms represents a disequilibrium and path dependent process. The attractiveness of different cities as locations for high-tech industries appears to be con- 
tinually changing. The goal of this paper is to determine the factors that are favourable for the city of Barcelona and which can indicate the potential success of such project.

The question of spatial concentration of firms in particular spatial areas is of high practical importance. Extensive empirical studies have been conducted (see, for example, Henderson, 1985 and Trullen, 1999) but there is no complete theoretical model describing this process. The goal of this study is to suggest a model for the process which also provides some testable formulae.

The empirical part of the paper presents the results of a questionnaire administered to firms, in which they note the factors that are important for their location.

\subsection{Basic literature}

On one hand, there is a body of literature on the micro mechanisms of functioning of increasing returns to scale in a dynamic framework. W.B. Arthur (1994) has several articles related to the urn mechanism that produces a path-dependent effect. In other words, when several firms (or locations) start some kind of competition in similar conditions, it is not clear which firm will win, but it is clear that the long-run outcome will be quite asymmetric and will depend on the history of random shocks.

On the other hand, there is extensive literature on urban economics, related to optimal city size (see Henderson, 1985 and Duranton and Puga, 2004).

This literature mostly deals with static problems, but at the same time accounts for the typical effects produced by geographical space.

Another branch of literature is related to the influence of externalities on productivity and costs. It starts with the works of Marshall (Marshallian externalities) and later expanded by Marshall himself (1890), Becattini (1979), Camagni (2005), Trullen (1999), etc.

Our goal is to combine these approaches. The urban economic literature will be useful for the determination of the effects that are responsible for scale economies, while Arthur's works will help us to predict the peculiarities of dynamic mechanism. 


\section{The Theoretical Model}

In the presence of scale economies and externalities, the structure of economic outcomes differs from those traditionally considered in the economic literature. The clustering of firms in the presence of scale economies leads to new patterns of equilibria. In a similar manner, each city may have several «vacant levels» for locations of technological firms but not all of them are necessarily occupied. As time goes by, some firms might shift between cities and new firms may emerge with locations in particular cities, so that the pattern has its own dynamics.

Here we have two types of interactions: a) between firm and a city (which depends on city size through the mechanism emerging from CBD theory, as is described below), b) between different firms in city (Marshallian externality), which depends on the number of firms.

\subsection{Competition under increasing returns to scale}

The traditional microeconomic literature typically stays away from scale economies, since they pose a problem either for an existence of equilibrium, or its stability $^{2}$. Another, dynamic, approach to modelling competition of this kind was proposed by W.B. Arthur, who focuses more on the dynamics of competition and analysis of the factors leading to the final outcome. In one of his works he considers competition between locations for attracting firms, when there exists a possibility of positive spillover. In the numerical simulation with a sequence of small random effects it is shown that the outcome is path dependent, i.e. in a symmetric initial situation the final outcome is quite asymmetric, but it is not clear which firm has an advantage.

Arthur's approach shows how the scale economies work through the intertemporary profit/, while each competitor grows randomly but has a unique optimal size that brings the highest profits. It was shown that even a small difference in initial conditions may have a major effect on the final probability of competitors to win the market.

${ }^{2}$ Krugman is the only author to study this equilibrium. It is necessary to assume DixitStiglitz preferences and the mechanism of scale economies working through an increasing number of varieties. 
In the present model, it is important to determine the location externalities that create Marshallian scale economies.

\subsection{Factors that determine scale effects}

It is well known that high-tech industries have significant positive externalities from location. The best known example is the phenomenon of Silicon Valley, where we observe a growing concentration of firms in one location. The reason for this concentration is to the existence of positive spillovers for firms located in one neighbourhood.

Not all firms will necessarily be located in one neighbourhood, because there are also congestion effects. But if the optimal number of firms in one location is finite, there will still be winning and losing locations.

What factors might be important for spillover effects between high-tech firms? At the level of managerial costs, shorter distances represent clear savings, but with the development of internet and mobile connection this factor becomes less important. The concentrated pool of diversified skill labour becomes decisive. London appears to have attained its leading position in the location of «white-collar» offices / because of its large population and concentration of knowledge. Barcelona obviously trails behind London in terms of population/ but it seems to have a high concentration of knowledge per capita.

As regards congestion effects, they are related not only to traffic, but also to housing and office rental prices. London seem to have very high congestion effects, and firms are thus obliged to pay very high wages, which still do not bring high utility to workers due to high living costs. In this regard, Barcelona was a very attractive location until 1998, but the housing price boom in Spain in the last ten/ years has eroded this advantage.

The empirical part of the paper presents the results of interviews carried out with firms, in which they determine factors that are important for their location. Results show that the differences in taxation laws across cities is an important source of heterogeneity (in this factor Barcelona is a loser, for example, to Bilbao and Dublin); Barcelona also has less experience and receives less state support for innovative and technological applied research; Barcelona has advantage in quality of life and leisure activities; its office space prices are still relatively low, but the positive trend in housing prices since 1998 has reduced the advantage it used to offer as a cheap city, where lower wages can be paid. The results of other studies have shown Barcelona is among 
the ten most attractive industrial locations in Europe/ : London and Paris remain in the lead, while other locations are not very far ahead of Barcelona

\subsection{Modelling the competition of cities for technological firms}

This model is highly stylized, as it keeps firms as identical a priori and only introduces the unique heterogeneity across cities, which is related to their population $\mathrm{N}$. Nevertheless, the model provides some analytical results that can be modified and adapted in order to solve more practical problems (section 3). We start from a static problem, where we have cities with different populations and different numbers of technological firms, both given as exogenous numbers. While both the populationsand total number of firms in cities evolves over time, this evolution is relatively slow, so in the short run we can concentrate on static problem, linked to some kind of equilibrium. In order to approach this problem, we assume freedom of firms to choose their location and inputs, as well as rational expectations of firms regarding the location of other firms. There will be a two-stage optimization process: in the first stage, firms calculate the optimal number of firms $M=M(N)$ in each city of size N. Due to Marshallian externalities, if this number is currently below $\mathbf{M}$, the growth until $\mathrm{M}$ is mutually beneficial for firms. In the second stage firms find a city with a population $\mathrm{N}$, that profit of each of $\mathrm{M}$ firms there is maximized. While this number is found using continuous optimization, in reality the problem is discrete: firms start to agglomerate in the city of optimal size, then other firms cluster in the second-best city, and so on. If the total number of firms is not particularly large, some cities will have an insufficient number of technological firms, or none at all.

While we do not specify different types of firms in the model, it is in fact more useful for technological firms, which are more subject to Marshallian externalities. The profit of a firm is the difference between revenues and costs, which depend on externalities. Since transport and trade costs are very small in the globalized world, especially for high-tech products, the difference in profit emerges at cost level. What costs depend on location?. It seems that the main effects come from office rent, wages and cost saving due to spillover.

We assume that the costs (per unit of output, or worker) of a representative hightech firm in a city have three components: office rent $\mathrm{C}_{\mathrm{r}}$, wage $\cos t \mathrm{C}_{\mathrm{w}}$ and communication cost (or spillover effect) $C_{c}$. The profit (per unit of output) is the revenue $R$ minus cost: 


$$
\pi=\mathrm{R}-\mathrm{C}_{\mathrm{r}}-\mathrm{C}_{\mathrm{w}}-\mathrm{C}_{\mathrm{c}} \text {. }
$$

Let $\mathrm{N}$ be the population of a city, and let $\mathrm{M}$ denotes number of firms in one location. As was shown in Appendix 1, the housing price index for a city depends on its population as $\mathrm{P}=\mathrm{a}+\mathrm{bN}^{1 / 2}$. If we assume that the major part of real estate is occupied by residents, firms should take this housing price $\mathrm{P}$ as given ${ }^{3}$.

Now we should determine the wage for skilled labour in a city as a function of its population $\mathrm{N}$ and the number of firms $\mathrm{M}$. At the first step, we abstract from the presence of international firms and define the wage index for labour only on the basis of city size $\mathrm{N}$; this will be a benchmark. As was shown in Appendix 1, basic wages are related to the city population as $\mathrm{w}=$ const $-\mathrm{F} / \mathrm{N}$. A brief derivation of the formulae for prices and wages as the function of city size is provided in the Appendix.

Now we assume that wage costs for high-tech firms represent the sum of the base wage bill (emerging from the market for unskilled labour) and the mark-up from the competition of high-tech firms for skilled labour. This mark-up (or skill labour wage premium) depends positively on the number of high-tech firms per capita, i.e. on $\mathrm{M} / \mathrm{N}$. The simplest function with this property is linear. Thus, we assume that the wage costs of a representative high-tech firm in a city with $\mathrm{N}$ inhabitants and $\mathrm{M}$ firms of this type is given by the expression:

$$
\mathrm{C}=\mathrm{c} 2+\cdot \mathrm{M} / \mathrm{N}=\mathrm{c} 1-\mathrm{F} / \mathrm{N}+\alpha \mathrm{M} / \mathrm{N}, \text { with } \alpha>0 .
$$

Finally, we assume that communication costs (Marshallian externalities) inversely depend on $\mathrm{M}: \mathrm{C}_{\mathrm{c}}=$, $\mathrm{M}$. Thus,

$$
\pi(\mathrm{M}, \mathrm{N})=\pi_{0}+\mathrm{F} / \mathrm{N}-\mathrm{bN}^{1 / 2}-\alpha \mathrm{M} / \mathrm{N}-\beta / \mathrm{M}
$$

Proposition 1. Scale economies work in such a way that a firm's profits depend both on city size and on the number of firms located there.

${ }^{3}$ Clearly, if there are as many firms as in Silicon Valley, it will mainly be the firms themselves that define rents for office space. 


\subsection{Solution to the optimization problem}

Here we proceed in two stages. At the first stage, firms take city size $\mathrm{N}$ as given and enter until the total number of firms $\mathrm{M}$ becomes optimal. Intuitively, if we have too few firms, the Marshallian positive externality is too small, while if there are too many firms, congestion effects (high rents for office space, high wages due to competition for skilled workers) dominate. Formally, we solve the equation

$$
\mathrm{d} \pi(\mathrm{M}, \mathrm{N}) / \mathrm{dM}=0 .
$$

Differentiation gives the optimal number of firms $\mathrm{M}$, depending parametrically on city size N:

$$
M^{*}=(\beta N / \alpha)^{1 / 2}
$$

Since the second derivative is always negative, we have a unique maximum.

Proposition 2. For each city of particular size $N$ there exists an optimal number of firms, when the profit of each one is maximized (for given city size). If there are too few firms, all of them are interested in further entrants, until an optimal level is reached.

From a practical point of view, many factors influence firms' profits besides city size. They cannot be modelled analytically. Section 3 of this paper will deal with this issue at the empirical level.

Now we substitute this expression and find profit as the function of $\mathrm{N}$ :

$$
\pi(\mathrm{M}, \mathrm{N})=\pi_{0}+\mathrm{F} / \mathrm{N}-\mathrm{bN}^{1 / 2}-2(\alpha \beta / \mathrm{N})^{1 / 2} .
$$

The new differentiation $\mathrm{N}$ gives the equation for the optimal size of a city (we introduce a new variable $x$ to have natural power in equation, $x=\mathrm{N}^{1 / 2}$ ):

$$
\mathrm{b} \mathrm{x} / 2-(\beta \alpha)^{1 / 2} \mathrm{x}+\mathrm{F}=0 .
$$

This equation may have 1 or 3 solutions, depending on the parameters. If we have a unique maximum, there exists an optimal city size $\mathrm{N}$, in which $\mathrm{M}=\mathrm{M}(\mathrm{N})$ technological firms enter and gain maximal profit. 
Numerical analysis of roots. The numerical analysis shows that we have one negative root and 0 or 2 positive roots. For example, for parameter values $b=1,,=1,{ }^{\cdot}=1$, $\mathrm{F}=0.25$, the roots are: $\mathrm{x}_{1}=-1.52, \mathrm{x}_{2}=0.258, \mathrm{x}_{3}=1.267$. The second derivative at $\mathrm{x} 2$ is positive (we obtain a minimum) and is negative at $\mathrm{x} 3$ (we obtain a maximum). Hence, $\mathrm{x} 3$ represents the optimal value of $\mathrm{x}$, and $\mathrm{N}$.

Comparative statics. An increase of parameter $\mathrm{F}$ from 0.25 to 0.5 (the rest of the parameters are kept as before) moves the roots: now $\mathrm{x}_{1}=-1.61, \mathrm{x}_{2}=0.618, \mathrm{x}_{3}=1.00$. Again, $x_{3}$ is the location of the maximum. A further increase in fixed cost $F$ leads to disappearance of both positive roots. What does this mean?

Different number of roots. Only positive roots make economic sense. There are at most 3 roots, and one of them is always negative. This is easy to see graphically, looking at equation $\mathrm{x}^{3}=\mathrm{ax}-\mathrm{c}$, which is topologically equivalent for $\mathrm{b}>0, \mathrm{~F}>0$. If there are two positive roots, only one of them is maximum, and from the firms' perspective we have a single optimal city size $\mathrm{N}$,. But there may be a case in which there are no positive roots at all (if $\mathrm{F}$ is high enough). In this case we have a corner solution: either $\mathrm{N}=0$ or $\mathrm{N}=\infty$. In reality, there is a discrete set of city sizes, and such a problem is solved by simple comparison and ordering of $\pi(\mathrm{M}(\mathrm{N}), \mathrm{N})$ w.r.t. existing set $\left\{\mathrm{N}_{1}\right.$, $\left.\mathrm{N}_{2}, \ldots \mathrm{N}_{\mathrm{k}}\right\}$..

Dynamics. Note that the presence of too few or too many firms is negative for firms. Therefore, nobody wants to be the first to enter; firms will appreciate an initial investment in infrastructure to enable the optimal number of firms to enter at the same time. The dynamic problem can be studied in «adiabatic» approximation, i.e. as a sequence of static equilibria, which move smoothly into each other. For this to take place, the speed of convergence to equilibrium must be faster than external changes (city growth or technological inventions, leading to the emergence of firms with new technology).

The perspective of the city. Now let us look at the problem from the city's perspective. We know that in the long run not all cities would attract optimal number of technological firms, and will thus become losers. While in the model cities are assumed to be identical, in reality they are heterogeneous. The main goal of our empirical study is to detect these sources of heterogeneity that give some cities an advantage in the competition for technological firms. 


\section{Empirical Analysis}

This model shows only the main cost components that are important for clustering of international firms in a particular centre. Since this competition between cities for firms has scale effects, initially the final outcome is unclear and depends on many additional factors, which are not always of economic origin and are not always quantifiable.

It is well known that investment in Research and Development and Innovation (henceforth abbreviated as $\mathrm{R}+\mathrm{D}+\mathrm{I}$ ) is a necessary precondition for technological growth and development. Firms of this type typically grow in clusters and are therefore relevant for our study. The Table 1 shows that Catalonia (and, to an even greater degree, Spain as a whole) is in a much weaker position than an average EU country.

Table 1. Data about R+D+I

\begin{tabular}{|l|c|c|c|c|c|}
\hline & Unit & Catalonia & Spain & Sweden (max) & EU-15 \\
\hline R+D+I as \% GDP & $\%$ & 1.20 & 1.03 & 4.27 & 2.0 \\
\hline
\end{tabular}

Source: Ministry of Science and Technlogy, Spain; EUROSTAT.

Whereas in the USA the private sector pays $70 \%$ of the costs of $\mathrm{R}+\mathrm{D}+\mathrm{I}$, the average level in the EU-15 is only $65 \%$. But the position of Spain is much worse: the private sector pays only $52.4 \%$ of the corresponding costs. The EU leaders are Sweden (with 77.6\%) and Finland (with 71.1\%). The role of the private sector there exceeds that of the USA, and hence these countries have a much greater advantage in the creation of industrial districts in Europe.

At the level of empirical methodology, the EUROSTAT data on metropolitan areas does not contain information that is relevant to our study. This is why we decided to administer the questionnaire.

In order to apply this methodology to the case of the city of Barcelona (and district22@ inside it), all available empirical material must be used, including company surveys and consultancies. 


\subsection{Non-Measurable Factors}

The studies by Xavier Vives and Lluis Torrens (2004) examined 32 European cities that can compete for location of clusters of international firms. They focused on three factors and ranked these cities with respect to them. The first factor that works as positive externality for location is related to leisure opportunities. Here, Barcelona is quite competitive, in fifth place out of 32, surpassed only by Paris, London, Madrid and Rome. Another source of positive externality is a spillover from local power (the so-called effect of capital), and here Barcelona, being only the regional centre of Catalonia, comes $12^{\text {th }}$. However since Catalonia is a relatively large region with almost 7 million inhabitants, Barcelona loses only to the capitals of larger countries. The third factor is the potential for research and development. Here, despite the existence of several universities, Barcelona falls to $21^{\text {st }}$ place. Here a longstanding problem re-emerges: Spain has never been a country with high investment in scientific research and has not promoted quality research schools.

Conclusion 1. While Barcelona has an advantage as a leisure-city, its political spillovers are limited and it is disadvantaged vis-à-vis many other cities in terms of the lack of tradition in applied scientific research oriented to technological development. This is why, at the first stage, it is unlikely to attract many Silicon-valley type firms, but can expect an initial clustering in arts and entertainment, with the possibility of becoming a Hollywood-type cluster. To reverse this trend, substantial regional-level investment in building applied research schools is necessary; however, this takes time, and competition from other cities will be strong.

\subsection{Measurable Cost/Benefit Factors.}

In the model, all measurable factors have been derived only from the size of a city. In reality, cities are heterogeneous: housing prices, for example, depend not only on city size, but on many other factors as well. Since office rental prices represent an important cost factor for a firm, it is worthwhile to compare this factor in different cities. In 2007, office rent in Barcelona was well below that in other cities (see Table 2). Paris and London have the highest prices, meaning that their advantage in non-measurable factors over Barcelona is at least partly offset by high prices for office space. 
Table 2. Rent price for office space, 2007 (in Euro/sq.m/ month)

\begin{tabular}{|lr|}
\hline London, WE & 126 \\
Paris & 84 \\
London, City & 81 \\
Frankfurt & 52 \\
Amsterdam & 48 \\
Madrid & 44 \\
Barcelona & 37 \\
Stambul & 24 \\
\hline
\end{tabular}

Source: Own calculations based on data from departament d'Estadística and CB Richard Ellis.

Now let us consider whether current office price is a good proxy for measuring firms costs in future equilibrium. This low price may be partly driven by the excess supply of offices over still moderate demand (many offices were constructed for the FORUM 2004, while Barcelona's low position in R\&D still keeps office demand at a moderate level).

Costs of firms will include future rental prices, and if many enter, prices for office space will rise substantially. Another cost is salary. For an international worker (and skilled workers are usually of this type) the nominal wage should be corrected by the cost of living index, and here housing prices (both to buy and to rent) matter. We cannot provide a fully quantified international comparison here, but the recent trend of housing prices in Barcelona (Table 3) shows that it is rapidly losing its comparative advantage in this area.

Table 3. Evolution of average prices of houses in Barcelona (in Euro/sq.m)

\begin{tabular}{|l|c|c|c|c|c|c|c|}
\hline & 2000 & 2001 & 2002 & 2003 & 2004 & 2005 & 2006 \\
\hline BARCELONA & 2.062 & 2.388 & 2.765 & 3.179 & 3.219 & 3.425 & 3.509 \\
\hline
\end{tabular}

Source: Own calculations based on data from departament d'Estadística. Ajuntament de Barcelona.

Conclusion 2. While Barcelona is still a cheap city for renting office space, its housing prices are already expensive, and firms will need to pay higher salaries than in some other cities (of similar size, such as Vienna) to attract skilled international labour. 


\subsection{The Strong and Weak Points of the Project 22@}

Table 4 represents a summary of the empirical analysis of the advantages and disadvantages of the emerging industrial district 22@ in Barcelona [see appendix 2].

Table 4. Advantages and disadvantages of district 22@

\begin{tabular}{|l|r|}
\hline Strong points of project 22@ & $\%$ \\
\hline Communication & $25,9 \%$ \\
\hline Technological image & $14,8 \%$ \\
\hline Good future expectations & $22,2 \%$ \\
\hline Infrastructures & $7,4 \%$ \\
\hline Quality of life & $3,7 \%$ \\
\hline Perspectives for contacts and business & $11,1 \%$ \\
\hline Price & $7,4 \%$ \\
\hline Facilities provided for local Government & $7,4 \%$ \\
\hline Total & $100,0 \%$ \\
\hline
\end{tabular}

\begin{tabular}{|l|r|}
\hline Weak points of project 22@ & $\%$ \\
\hline Public transport, mobility & $26,1 \%$ \\
\hline Area under development; uncertain future & $17,4 \%$ \\
\hline Enivronment & $4,3 \%$ \\
\hline problems of good supplies & $4,3 \%$ \\
\hline Lack of services & $21,7 \%$ \\
\hline Problems with parking & $4,3 \%$ \\
\hline Insufficient infrastructures in initial period & $8,7 \%$ \\
\hline High land price & $4,3 \%$ \\
\hline Dificulties for small firms & $4,3 \%$ \\
\hline None=Rest & $4,3 \%$ \\
\hline Total & $100,0 \%$ \\
\hline
\end{tabular}




\subsection{More Detailed Results of Barcelona Survey}

The study of information supplied verbally requires different techniques of analysis. First we focus on the most frequently repeated phrases in answers.

1. The majority perceive the project $22 @$ to be linked to new technologies and knowledge.

2. At the same time, there has been little international involvement in this project, perhaps due to insufficient publicity and the very low number of international firms already there.

3. The most positive aspect of project 22@ is related to the good expectations for future, the belief in the emergence of networks between universities and firms with high technology, new infrastructures, the emergence of a large-scale technological centre.

4. The perceived weakest points are the slow pace of the project, low quality infrastructures, insufficient services and marketing, and insufficient attempts to attract firms with high technology.

5. People compare this project with Silicon Valley, the agglomerations of New York and Boston in the USA, and London in the UK, and with technological developments in countries like Ireland and Sweden.

6. People believe that the following aspects are decisive for project 22@: technological atmosphere, prices, expectations for future, communications, and availability of space. (Note that at the theoretical level these issues deal with scale economies and describe very vulnerable and pass-dependent environment which may reach different equilibria depending on the interplay between these factors.)

7. District 22@ also competes with other locations in Barcelona such as the Zona Franca, El Prat, Sant Cugat, etc. Their main advantage is in land price. (Due to scale economies, only one winner is likely to emerge, and if 22@ is much stronger than competitors, it will save energy for internal competition in order to contribute to Barcelona's competitive power in the international market for attracting firms.)

What types of firms have located in district 22@? The answers to the questionnaire shows that they are mostly medium-size firms, mostly in the audiovisual sector, graphic arts, telecommunications [see appendix 3]. 
The strong points of Barcelona in international competition for firms are related to its good access to markets, its good communications and its prestige. The lack of public sponsorship of Research and Development is one of the factors that weaken Barcelona. District 22@ has high expectations for future due to its technological image, but the uncertain future of the district in general (Poblenou, Sant Marti), due to its currently low level of quality services and public transport, weaken this position.

It is believed that firms based on new technologies and services for other firms will be the main contributors to the growth of this zone.

\subsection{Conclusions Based on Survey [appendix 2]}

1. The main goal of the project 22@ is to attract high technology firms that will not only establish Barcelona as a newly emerging technological centre, but will help the city to improve its position in the hierarchy of European industrial centres.

2. At the present time, the majority of firms that have already located in the $22 @$ district, are not international and are not high-tech. To encourage international firms with high technology to locate here, higher levels of infrastructure, public services and human capital are necessary.

3. One of the problems of Barcelona is the lack of political power and the fact that it is not the capital city (here it loses to Madrid). The second important problem is the advantage of the first movers in establishing European districts of hi-tech industry. In this respect, several European cities (for instance, Stockholm, Helsinki, more recently Dublin) are already operative in this market. This is extremely important, since these districts possess self-reinforcing effects coming from the economies of scale created by centripetal forces.

4. Another important problem facing Barcelona (and Spain in general) is the excessively low public investment in applied research. This creates a lack of he human capital that international hi-tech firms are looking for, despite the high general level of education in this city.

5. While 10 years ago Barcelona was a very attractive place for location due to moderate housing prices, this advantage has disappeared in recent years, as the housing price indices have doubled or even tripled. Housing prices are still lower than in London or Paris, but no longer low enough to compensate for the other disadvantages.

6. On the other hand, the city of Barcelona has a very positive image and has the 
potential to become a city of this type. It is famous for its art and architecture and has experience of organizing public forums, such as the 1992 Olympic Games.

7. In this situation, it is very important that local government should make the initial push to attract firms of the desired type to district 22@ before the market creates conditions for the further self-reinforcing growth of this cluster.

\section{Conclusions}

This article combines a theoretical model and its empirical application to the potential consequences of the project 22@, the technological district of Barcelona. Optimal selection of locations by firms in the presence of spillover effects leads first to clustering and then to competition of metropolitan areas for these clusters. Since we have more space for firms in cities than the number of firms, in the presence of scale effects, not all cities will win such a competition. In the stylized model, only size of city matters (acting through its influence on costs and benefits), and the city of optimal size will attract the optimal number of firms, which will form a cluster that is mutually beneficial for them and the city. At the same time, it becomes clear that some cities will be winners and others losers in the competition for technological firms.

In reality, there are different types of firms (local, national and international) and there is heterogeneity across the cities (not only size, but also other factors matter). We try to identify the factors other than size that can give an advantage to a city, and then apply this approach to the case of the city of Barcelona and its technological district 22@.

The results of the survey/ show that:

- We can divide the factors into 3 groups: operative (quality of infrastructure, proximity of markets, labour skills) economic (fiscal and labour laws, wages, help of local government), and local (quality of life, existence of specialized labour, experience and state support for $\mathrm{R}+\mathrm{D}+\mathrm{I})$;

- The differences in taxation laws across cities is an important source of heterogeneity (in this factor Barcelona is a loser, for example, to Bilbao and Dublin);

- Barcelona also has less experience and state support for innovative and technological applied research;

- Barcelona has advantages in quality of life and possibilities of leisure; 
- Barcelona still has relatively low prices for office space, but the positive price trend in housing prices since 1998 has reduced the advantage it used to have as a cheap city, where lower wages can be paid.

\section{LiTERATURE}

Abdel-Rahman, H. M. and Anas, A. (2004) Theories of systems of cities. - In: J.V.Henderson, J.-F-Thisse, Eds.: Handbook of Urban and Regional Economics. Vol.4. Cities and Geography. Horth-Holland: Elsevier, pp.2293-2340.

ARThuR, W.B. (1994) Increasing Returns and Path Dependence in the Economy. - Michigan Press, $201 \mathrm{p}$.

Becattini, G. (1979) Dal «settore» industriale al «distretto» industriale: alcune considerazioni sull’unita di imagine dell’ economia industriale. - Rivista di Economia e Politica Industriale, 1, pp.7-21.

Camagn, R. (2005) Economia Urbana. - A.Bosch, Ed., Barcelona. 303 p.

Datar Reclus 1994 - Les villes Européennes», Paris.

Duranton, G. and Puga, D.(2004) Micro-foundations of urban agglomeration economies. In: J.V.Henderson, J.-F-Thisse, Eds.: Handbook of Urban and Regional Economics. Vol.4. Cities and Geography. Horth-Holland: Elsevier, pp.2063-2118.

Eluison, G. and Glaeser, E. (1997) Geographic Concentration in US Manufacturing Industries: A Dartboard Approach. - Journal of Political Economy, v.105, p.889-927.

EUROPEAN INVESTMENT MONITOR 2001, 2002,2003, ERNST \& YOUNG.

Henderson, J.V. (1985) Economic Theory and the Cities. - Orlando, Academic Press.

Marshall, A. (1979) Principles of Economics. - Macmillan, London (The first edition 1890).

Trullen, J. (1999): La Catalunya - Ciutats. - Revista econòmica de Catalunya, Generalitat de Catalunya, Barcelona.

Vives, X. and Torrens, Ll. (2004). El posicionament de la Regió Metropolitana de Barcelona davant les regions europees. Nota d'Economia, No. 79, 2004 , pags. 103-128.

Yegorov, Yuri y Mascarilla, Òscar (2005), «Spatial Aglomeration of Firms - Theory and Application for Industrial District 22@ of Barcelona», ERSA conference papers, European Regional Science Association. 


\section{ApPENDices}

\section{Appendix 1: A Model of Optimal City}

We will first derive how wage depends on city size, and then find the relationship between city size and housing price. Thus, we will obtain the attractiveness of a city as a function of its population.

How does the wage depend on city size?

We assume that each city has a firm which operates with zero profit (in a monopolistic competitive environment). Thus, the benefits from sales should cover fixed costs and the rest should be split across labour and capital. For Leontieff production function, it is optimal to operate with equal size of inputs; hence, $Q=K=L$. Now we will rely on a stylized fact/ of perfect capital and imperfect labour mobility. Due to perfect competition in financial markets and perfect capital mobility, every unit of capital receives the same return $r$, while labour may obtain different returns in different cities. Hence, we obtain $\mathrm{pL}=(w+r) \mathrm{L}+\mathrm{F}$. Since $\mathrm{L}=\mathrm{N}(\mathrm{i})$, the expression for the wage is the following:

$$
\mathrm{w}(\mathrm{i})=\mathrm{p}-\mathrm{r}-\mathrm{F} / \mathrm{N}(\mathrm{i})
$$

In fact, the wage depends on city $\operatorname{sizew}(\mathrm{N})=\mathrm{C}-\mathrm{F} / \mathrm{N}$. This function is concave in $\mathrm{N}$ : w'>0, w" $<0$. Very small cities simply cannot exist (wage should be negative), while for very large cities the wage approaches its upper limit: $\mathrm{w}($ ? $)=\mathrm{C}$.

Housing price and city size

Consider a city as monocentric CBD, with $r$ as the distance from the city centre (Alonso model). For simplicity, we assume linear transports cost and will abstract from the distance effect on dwelling size as well as on the height of the buildings.

The housing price, $\mathrm{P}_{h}$, is assumed to be a linear function of location rent $R(r)$ :

$$
\mathrm{P}_{\mathrm{h}}(\mathrm{r})=\mathrm{R}(\mathrm{r})+\mathrm{H}
$$

where $\mathrm{H}$ denotes construction cost, equal for all locations. At the edge of the city, the location rent is equal to agricultural rent $R_{a}$, which is assumed to be a constant, regardless of location. Then, the location rent in the centre $R(0)=R_{a}+t r^{*}$, where $t$ 
is the unit distance transport cost. Assume that a city has a radius $\mathrm{r}^{*}$. Then its population equals to $\mathrm{N}=\rho \pi\left(\mathrm{r}^{*}\right)^{2}$. Hence,

$$
\mathrm{r}^{*}=[\mathrm{N} /(\rho \pi)]^{1 / 2}
$$

The housing price in city centre is $\mathrm{P}_{h}(0)=\mathrm{R}_{\mathrm{a}}+\mathrm{H}+\mathrm{tr} \mathrm{r}^{*}$. It will be considered as the housing price index, or cost of living, for the whole city: $\mathrm{P}(\mathrm{i})=\mathrm{P}_{\mathrm{h}}(0)$. The reason is that only the residents in this area do not face transport costs, and this price exactly equals the sum of housing rental price plus internal transport costs for the whole city. This cost of living in a city contains a term proportional to a square root of its population:

$$
P(i)=a+b N(i)^{1 / 2} \text {. }
$$

It is also concave in $\mathrm{N}$, but the shape differs from $\mathrm{w}(\mathrm{N})$.

\section{Appendix 2: ENQUESTA PER LES EMPRESES DE L'ÀMBIT 22@ (Questionary and interview in Catalan)}

\section{Dades generals de L'Empresa}

1. Nom

2. Any de fundació

3. Sector d'activitat

4. Nombre de treballadors

5. És filial d'un grup multinacional?

6. Propietat del capital ( aproximadament)

- Espanyol $\%$

- Estranger $\%$ De quins país?

7. Estava instal·lada al districte abans del projecte $22 @$ (abans de juliol del 2000)?

- Sí

- No

NOTA: Per les preguntes on s'ha de valorar d'1 a 10, s'entendrà que la millor puntuació possible que es pot donar és de 10. 
2. Sobre la ciutat Regió de Barcelona

8. Citi els punts forts de localitzar la seva empresa a la ciutat - regió de Barcelona respecte altres ciutats - regió (ex: Madrid, resta d'Europa, etc.)
a)
b)
c)

9. Citi els punts dèbils de localitzar la seva empresa a la ciutat - regió de Barcelona respecte altres ciutats - regió (ex: Madrid, resta d'Europa, etc.)
a)
b)
c)

3. Sobre El Sector 22@ EN General

10. Citi els punts forts de localitzar la seva empresa al districte 22@
a)
b)
c)

11. Citi els punts dèbils de localitzar la seva empresa al districte 22@
a)
b)
c)

12. Creu que la imatge 22@ (localitzar-se a l'àmbit 22@) aporta valor afegit a la imatge de l'empresa? (Puntuar d'1 a 10)

13. En quina mesura afecta positivament conèixer que altres empreses del sector decideixen instal·lar-se al districte d'activitats 22@bcn? (Puntuar d'1 a 10)

14. Creu que el districte d'activitats 22@ afavoreix la innovació? (Puntuar d'1 a 10) 
15. En quina mesura creu que es dóna l'anomenat «efecte contagi o desbordament del coneixement» (és a dir, el fet de que el coneixement d'una empresa afavoreixi altres empreses)? (Puntuar d'1 a 10)

16. A quin tipus d'empresa (o sector) creu que beneficia en major mesura instal·lar-se a l'àmbit 22@?

a) Empreses relacionades amb les noves Tecnologies de la Informació i la Comunicació (TIC)

b) Indústria tradicional

c) Serveis a empreses

d) Serveis financers

e) Altres

17. Quin sector d'activitat creu que serà el de major creixement a l'àmbit 22@? (Ex: audiovisual, moda, alimentari, TIC, serveis a les empreses, serveis financers, etc.)

18. Es planteja un canvi d'ubicació?

- Sí. En cas afirmatiu, on tindria pensat traslladar la seva empresa?

- Catalunya

- Resta d'Espanya

- Unió Europea

- Altres localitzacions

- No

19. Es planteja ampliar l'empresa?

- Sí. En cas afirmatiu, on es donaria aquesta ampliació?

- Al mateix districte 22@

- Resta de Barcelona

- Resta de la Regió Metropolitana de Barcelona

- Resta de Catalunya

- Resta d'Espanya

- Unió Europea

- Altres localitzacions 
20. Quins motius han portat a l'empresa a instal·lar-se al 22@? (Puntuar d'1 a 10)

- Accés al consumidor / mercat

- Accés a serveis (logística, informàtica, màrqueting)

- Accés a treball especialitzat

- Accés a serveis públics

- Accés a la informació

- Centralitat

- Infrastructures

- Flexibilitat dels espais productius

21. Valorar les següents característiques de l'espai 22@: (Puntuar d'1 a 10)

- Centralitat i accessibilitat

- Massa crítica

- Complexitat d'usos diversos (barreja d'usos)

- Infrastructures

- Flexibilitat i eficiència dels espais productius

- Centres de formació, recerca, divulgació de tecnologies, etc.

- Espai públic de qualitat

- Altres

4. Sobre la ubicació / accessibilitat al Districte 22@

22. Puntuar d'1 a 10 l'accessibilitat a la seva empresa en quant a:

- Transport públic (autobusos, metro, tramvia, etc.)

- Transport privat (en quant a tràfic, congestió, etc.)

23. Puntuar d'1 a 10 l'accessibilitat a altres ciutats de:

- La Regió Metropolitana de Barcelona

- Resta de Catalunya

- Resta d'Espanya

- Resta d'Europa

- Resta del món 
24. Ser perifèria d'Europa és un problema en quant a costos de transport i comunicació?

- És un problema greu

- És un problema poc important

- No és un problema

25. Puntuar d'1 a 10 la importància que dóna la seva empresa pel seu funcionament de:

- Arribada del tren d'alta velocitat

- Existència d'aeroport amb vols transoceànics

- Millora de la xarxa d'autopistes

5. Sobre les CONDicions de Demanda i L'estructura de Cluster

26. En quina mesura la seva producció o servei es dirigeix al:

- Mercat regional (Regió Metropolitana de Barcelona) $\%$

- Resta mercat espanyol $\%$

- Mercat internacional (exportacions) $\%$

27. Els vostres proveïdors solen ser: (Encerclar un màxim de 2 respostes)

- Altres empreses de 1'àmbit 22@

- Altres empreses de la Regió Metropolitana de Barcelona

- Altres empreses catalanes

- Altres empreses espanyoles

- Empreses estrangeres

28. Existeix cooperació entre les empreses del sector?

- Sí. De quina manera es dóna aquesta cooperació?

- En processos d'innovació

- Accés a informació

- Altres

- No

29. Realitza activitats de $\mathrm{R}+\mathrm{D}$ ?

- Sí

- No 
30. Els treballadors de la seva empresa tenen estudis:

- Primaris $\%$

- Secundaris $\%$

- Superiors $\%$

- Sense estudis $\%$

31. Personal dedicat a $\mathrm{R}+\mathrm{D}$ (indicar el número de persones):

- Titulats superiors:

- Tècnics de nivell mitjà:

32. Col-labora regularment en activitats de $\mathrm{R}+\mathrm{D}$ amb altres empreses?

- Si. En aquest cas, les empreses amb les que col·labora són:

- Altres empreses de l'àmbit 22@

- Altres empreses de la Regió Metropolitana de Barcelona

- Altres empreses catalanes

- Altres empreses espanyoles

- Empreses estrangeres

- No

33. Subcontracta regularment activitats de $\mathrm{R}+\mathrm{D}$ ?

- Si. En aquest cas, les empreses subcontractades són:

- Altres empreses de 1'àmbit 22@

- Altres empreses de la Regió Metropolitana de Barcelona

- Altres empreses catalanes

- Altres empreses espanyoles

- Empreses estrangeres

- No

34. És la vostra empresa subcontractada per realitzar $\mathrm{R}+\mathrm{D}$ per a altres empreses?

- Si. En aquest cas, les empreses que el subcontracten són:

- Altres empreses de l'àmbit 22@

- Altres empreses de la Regió Metropolitana de Barcelona

- Altres empreses catalanes

- Altres empreses espanyoles

- Empreses estrangeres

- No 
35. Col-labora regularment amb centres universitaris o altres institucions, ja siguin privades o públiques, en matèria de $\mathrm{R}+\mathrm{D}$ ?

- Si. Amb quins? (indiqui la naturalesa privada o pública del centre amb el que col·labora)

- No

36. Nombre de patents concedides a la seva empresa en els darrers 4 anys

6. Sobre variables culturals (Qualtat de vida / Formació)

37. Fins a quin punt és rellevant que els treballadors de la seva empresa dominin altres idiomes? (Puntuar d'1 a 10)

38. Quina formació necessària per la seva empresa troba a faltar al mercat laboral català?

39. Han influït en la seva decisió de localització variables de tipus cultural com la qualitat de vida, l'oferta d'activitats d'oci, etc.?

- Si. Puntuar d'1 a 10 en quina mesura aquestes variables de tipus cultural han influït en la seva decisió de localització

- No

7. ReCOMAnACIONS

40. Quines millores introduiria al districte d'activitats 22@?

41. Quines iniciatives polítiques proposaria? 


\section{Appendix 3}

\begin{tabular}{|l|l|}
\hline Firms 22@ & Pich - Aguilera arquitectos \\
\hline International Sound Studio & SB Hotels \\
\hline Sonoblok & Aigües de Barcelona \\
\hline Grupo Auna (2 localitzacions diferents) & Barcelona Activa \\
\hline Teletech & Universitat Oberta de Barcelona \\
\hline General Electric & Barcelona Televisió (BTV) \\
\hline Fòrum 2004 & Universitat Pompeu Fabra \\
\hline Ecotècnia & Bau escola de disseny \\
\hline Antonio Miró & Agència catalana de protecció de dades \\
\hline T-Systems & American Express \\
\hline Fotoprix & Barcelona Emprèn \\
\hline Liberty seguros & Caser \\
\hline Barthes\&Bold & Celer Pawlowski \\
\hline Blue Moon & Differend Games \\
\hline Charmex Internacional & Maaf \\
\hline Comecha & Rodamco Europe \\
\hline Impala Network Solutions & Sertec Soluciones informáticas \\
\hline GTD Ingeniería de sistemas y de software & STE Consulting \\
\hline Incotron & Sud América \\
\hline M3 Merchandising & Catalana de marketing telefónico \\
\hline Mecco & Iberphone \\
\hline Servi Grup Estudio & Atrápalo.com \\
\hline Tecnosigns & Barcelona Activa \\
\hline Tedelca Comunicaciones & Localret \\
\hline
\end{tabular}

